\title{
Foams as carrier systems for pharmaceuticals and cosmetics
}

\author{
DÓRA FARKAS, NIKOLETT KÁLLAI-SZABÓ, ISTVÁN ANTAL* \\ Department of Pharmaceutics, Semmelweis University, Högyes Str. 7., Budapest, H-1092 \\ *Corresponding author: István Antal \\ E-mail: antal.istvan@pharma.semmelweis-univ.hu
}

Received: 21 January 2019 / Accepted: 8 February 2019 / Published online: 4 April 2019

\begin{abstract}
Foams are becoming more and more popular in several areas of our lives, including pharmaceutics and cosmetics. They are colloid systems where gas is dispersed in a liquid phase. Active ingredient bearing pharmaceutical foams are traditionally applied topically (dermal, local rectal, vaginal), but formulations for other delivery routes (e.g. nanosystems parenterally, solid foams orally) are also available. Numerous advantages are attached to foams when compared to traditional vehicles, resulting in increased patient compliance. Amongst others, the suitable composition contributes to quick, oily residue free and convenient application even on large or hairy areas, as well as to good drug transfer rate.
\end{abstract}

Keywords: foam classification and characterization, formulation, excipients, image analysis

\section{Introduction}

According to the conventional classification of colloid systems, foams (Figure 1) are defined as discontinuous gas bubbles dispersed in a continuous phase (liquid or solid). Solid foams include thin polymer walls, while traditional liquid foams contain thin liquid films separating gas bubble agglomerations [1]. Foams can also be described as deformed (laminar difform) lyosols because the dispersing phase is a colloid. The thickness of the lamellae separating the bubbles is in the micronanometer range [2].

There are non-aqueous foams too, which with-

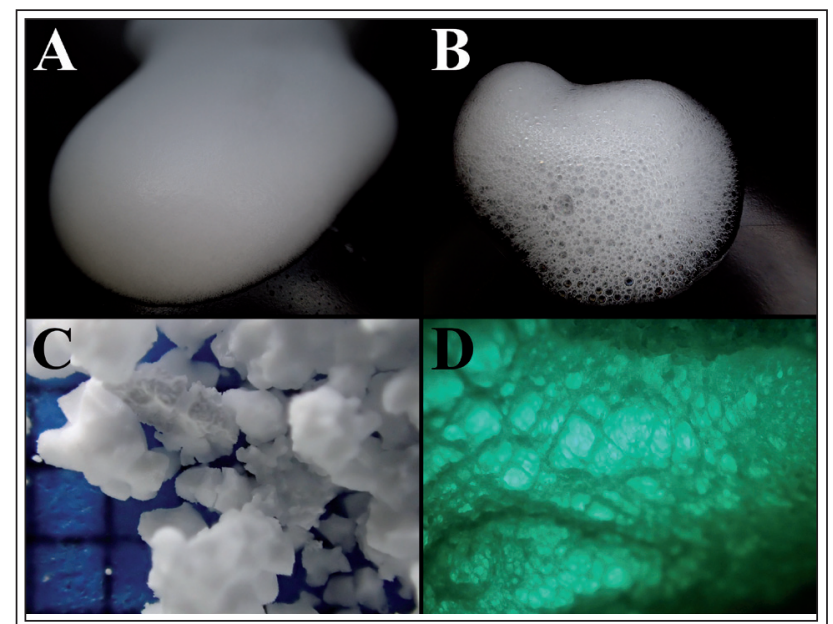

Figure 1 Aerosol foam (A); propellant-free foam (B); solid polypropylene foam particles $(C)$; stucture of a gum based solid foam (D) out the increase in the liquid phase viscosity, gelling, or solidification caused by cooling or polymerization are only stable for a short time. Due to their low density, good heat-insulating ability, and great mechanical solidity despite the small weight, these solid foams (xerosols, xerogels) are of great industrial significance in several areas, including pharmaceutical industry [2]. Gelatine or collagenbased solid foams, or sponges, containing antibiotic or steroid active ingredients are often used as primary wound dressings [3]. The mutual attribute of all foams that distinguishes them from sponges, irrespectively of the state of the film, is the enclosed bubbles and the lack of connection with the surrounding bubbles, so the gas phase is discontinuous while the liquid or solid phase is continuous [1].

\section{Foam formation}

Foams can be produced by two basic methods. The more common, mechanical one is by dispersing the gas phase in the liquid with beating or shaking [2]. The other way is by the gas-supersaturation of the liquid. The gas can be dissolved under pressure that is later released or can be formed in situ [4]. In both cases, the lifetime of the foams made of pure liquids is quite short [2]. For an enduring dispersion, the presence of surface active agents absorbing spontaneously onto the interface is essential. These amphipathic molecules have polar groups that contact with the water and also a hy- 
drophobic part that orients towards the gas and so creating a monomolecular layer. Surfactants reduce the energy required for foam formulation by decreasing the surface tension. They also foster the creation of an elastic boundary layer thus increasing the lamella stability by inhibiting their tapering. This progress can be hindered in different ways: by the presence of hydration shell of the surfactant molecules or by the repulsion of the ionic surfactant's electric charges. Another way is by the bulking of partially solvating particles, that reduce the system's free energy with the amount of adhesion work $\left(\mathrm{W}_{\mathrm{a}}\right)$, at the interface $[2,5]$.

$$
W_{a}=\gamma \cdot a^{2} \cdot \pi \cdot[1 \pm \cos \theta]^{2}
$$

where $\gamma$ is the surface tension, $a$ is the radius of the particle and $\theta$ is the contact angle [2].

Aerosol foams are formed due to the overpressure (usually 2-4 bars) when upon actuation the propellant evaporates quickly from the liquid. Delayed foam formulation can be reached by using a propellant with a high boiling point [6].

\section{Foam stability}

Due to the excess interfacial Helmholtz free energy, the foams are thermodynamically unstable but can have kinetic stability in case of hampered phase disunion [5].

Ensuring good stability is essential for effective foam forming. Without decent firmness, the structure is to break down partially resulting in increased bubble sizes. There are several events occurring simultaneously in foams that influence their stability.

Liquid evaporation itself can destroy the foam structure. The type of the surfactant used can influence the speed by altering the nature of the monolayer and result in reduced evaporation [7].

It is known, that the smaller volume phase has higher vapor pressure and better solubility. As a result of the difference in the vapor pressure of various sized bubbles, the smaller ones disappear gradually. This is called Ostwald ripening or disproportionation and it can also be affected by the nature of the monolayer or the type of gas used. The more water-soluble gas results in less stable foams, since it is transported quicker across the films $[7,8]$.

Owing to buoyancy force, in a few minutes after foam forming a creamy layer is observable on top of the liquid phase. Creaming is slower in concen- trated dispersions. Creaming and drainage lead to the break-down of foams. Curved liquid surface results in lower Laplace pressure (curvature pressure, capillary pressure) in the middle than around. This capillary downdraft results in

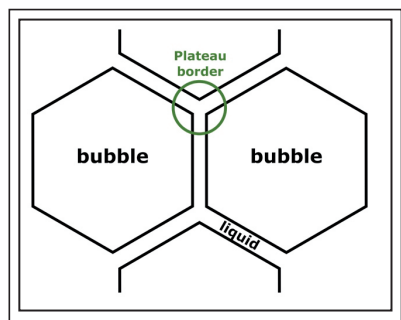

Figure 2 The structure of Plateau border decreased water volume in the foam and causes the thinning of the liquid film. When the dispersed volume fraction is about $60 \%$, the bubbles deform each other resulting in a polyhedral foam. The lamellae meet each other at 120-degree angles, forming a channel called Plateau border (Figure 2) [2,4,7].

The lifetime of foams can be elongated by increasing the viscosity of the liquid phase by adding e.g. polymers [2]. It is known, that even thick foam films can be stabilized by a low concentration polymer-surfactant complex. Given higher concentrations, uneven film thickness can be observed due to the aggregated complexes [9].

\section{Medicated foams}

The European Pharmacopoeia defines medicated foams (musci medicati) as preparations for skin or mucosal applications that consist of large volumes of gas dispersed in a liquid. They usually contain one or more active ingredients, surfactants for foam formation and other excipients. The liquid formulation is filled into a pressurized container that is equipped with a valve suitable for the ex tempore foam formation at the site of application [10].

The composition of the foam formulation, the type and amount of propellant highly influence the properties of the foams. The properties of an ideal medicated foam from the perspective of the patient:

- the easy application even on bigger, hirsute or sensitive, inflamed areas,

- stable and does not collapse, or drain for a short period post-expelling,

- persist while manipulation - e.g. lifting off a surface with an applicator for application on the skin,

- good spreadability - low shear is enough to destroy, thus slight rubbing is sufficient,

- drug delivery ability at least as good as conventional transdermal formulations,

- less oily residues than creams, ointments, [11]

- easy removal, in case it is needed, 
Table I Some examples of medicated foam formulations

\begin{tabular}{|c|c|c|}
\hline $\begin{array}{l}\text { Active pharmaceutical } \\
\text { ingredient }\end{array}$ & Indication & Product examples \\
\hline azelaic acid & mild to moderate rosacea & Finacea ${ }^{\circledR}$ Foam (Bayer) \\
\hline betamethasone valerate & $\begin{array}{l}\text { corticosteroid sensitive scalp dermato- } \\
\text { sis }\end{array}$ & $\begin{array}{l}\text { Luxiq }^{\circledR} \text { (Stiefel Laboratories Inc.). Beta- } \\
\text { methasone valerate } 0.12 \% \text { Topical Foam } \\
\text { (Mylan N.V.) }\end{array}$ \\
\hline budesonide & colitis ulcerosa & $\begin{array}{l}\text { Budenofalk }^{\circledR} \text { (Dr. Falk Pharma GmbH), } \\
\text { UCERIS }^{\circledR} \text { Rectal Foam (Salix Pharmaceuti- } \\
\text { cals Inc.) }\end{array}$ \\
\hline calcipotriene & plaque psoriasis (adults) & Sorilux ${ }^{\circledR}$ (Mayne Pharma) \\
\hline calcipotriol, betamethasone & psoriasis (adults) & Enstilar $^{\circledR}$ (LEO Pharma) \\
\hline clindamycin & acne vulgaris (above 12 years) & Evoclin $^{\circledR}$ (Stiefel Laboratories Inc.) \\
\hline clobetazol propionate & plaque psoriasis (above 12 years) & Olux $^{\circledR}$ (Stiefel Laboratories Inc.) \\
\hline $\begin{array}{l}\text { common witch hazel ex- } \\
\text { tract, } \alpha \text {-bisabolol }\end{array}$ & decubitus & $\begin{array}{l}\text { TEVACARE antidecubitus foam spray } \\
\text { (Laboratorium Dr. Deppe) }\end{array}$ \\
\hline desonide & atopic dermatitis & Verdeso $^{\circledR}$ (Aqua Pharmaceuticals) \\
\hline $\begin{array}{l}\text { dexpanthenol, bisabolol, } \\
\text { Vitamin A, E and F }\end{array}$ & sunburn, skin irritation & Panthenol Foam (Dr. Müller Pharma) \\
\hline $\begin{array}{l}\text { dexpanthenol, lidocaine, } \\
\text { sodium sulfosalicilate sa- } \\
\text { marate }\end{array}$ & superficial burns, running sores & Phlogosam (PannonPharma Kft.) \\
\hline hydrocortisone & colitis ulcerosa & Colifoam $^{\circledR}$ (Meda Pharmaceuticals) \\
\hline hydrocortisone acetas & adjuvant therapy of ulcerative proctitis & Cortifoam ${ }^{\circledR}$ (Alaven Pharmaceutical LLC) \\
\hline hydrocortisone, pramoxine & $\begin{array}{l}\text { inflamed, itchy manifestations of corti- } \\
\text { costeroid sensitive dermatosis }\end{array}$ & EpiFoam $^{\circledR}$ (Alaven Pharmaceutical LLC) \\
\hline ketoconazole & seborrhoeic dermatitis (above 12 years) & $\begin{array}{l}\text { Extina }^{\circledR} \text { (Stiefel Laboratories Inc.), Ketocon- } \\
\text { azole Foam 2\% (Perrigo Company Plc) }\end{array}$ \\
\hline minoxidil & alopecia & $\begin{array}{l}\text { Minoxidil Topical (Publix Super Markets } \\
\text { Inc) }\end{array}$ \\
\hline pramoxine, hydrocortisone & $\begin{array}{l}\text { temporary relief of rectal inflammation, } \\
\text { itching, pain, and swelling associated } \\
\text { with hemorrhoids, fissures, cryptitis, } \\
\text { proctititis }\end{array}$ & $\begin{array}{l}\text { ProctoFoam }{ }^{\circledR} \text {-HC (Alaven Pharmaceutical } \\
\text { LLC) }\end{array}$ \\
\hline sodium fluoride & caries protection & Oral-B ${ }^{\circledR}$ Minute-Foam ${ }^{\circledR}$ (Procter \& Gamble Co.) \\
\hline sodium sulfacetamide & seborrhoeic dermatitis, seborrhea sicca & Ovace ${ }^{\circledR}$ Plus (Espada Dermatology) \\
\hline tolnaftate & tinea pedis, tinea corporis & FungiFoam ${ }^{\circledR}$ (The Tetra Corporation) \\
\hline $\begin{array}{l}\text { 2QR bio-active bacterial } \\
\text { blocker }\end{array}$ & chicken pox & PoxClin $^{\circledR}$ (TRIMB HealthCare) \\
\hline- & cleansing, restoring and protecting skin & $\begin{array}{l}\text { Tena Wash Mousse (Essity Hygiene and } \\
\text { Health AB) }\end{array}$ \\
\hline
\end{tabular}

- non-irritant, non-toxic, non-allergenic, pharmacologically inert vehicle.

The drug transfer rate of foams is influenced by the significant physicochemical changes that the formulation undergoes while and after actuation from the container. When topically applied, the quick evaporation of the propellant causes increased active ingredient concentration, in some cases even supersaturation, that increases the absorption rate of foams [12].
A couple of pharmaceutical foams are available in Hungary and foreign countries and their indications for use are listed in Table I [11,12].

\section{Classification of foams}

In the field of pharmaceutics and cosmetics, the most used foams belong to aerosol foams, that are pressurized semi-solid formulations in aerosol cans. 


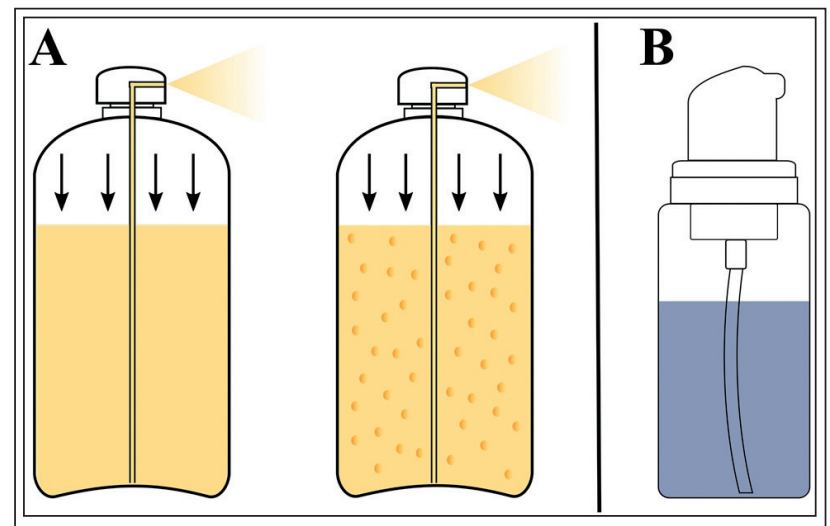

Figure 3 Scheme for two- and three phase foams in aerosol cans (A); propellant-free pump device (B)

Foams can be classified in several ways. We can differentiate aqueous, hydroethanolic and emollient foams as well as petrolatum-, oil- or other solvent-based foams too [13].

Emollient foams, as traditional creams or lotions, are emulsion-based so have a soothing, moisturizing effect. $\mathrm{O} / \mathrm{W}$ or $\mathrm{W} / \mathrm{O}$ emulsions can be used for the formulation, where the oil phase consists of mineral oil, triglyceride, fatty acid esters, such as isopropyl myristate, or isopropyl palmitate, or essential oil. Omega- 3 and 6 oils can also be used for therapy, or silicone oils for their protective nature. Rarely petrolatum is used, but for its greasy, cloth-staining properties. Emollient foams are complicated systems, even a small change in the composition can lead to the destabilization of the foam [14]. At body temperature, they are relatively stable, but the easy application on large target area is guaranteed by shear force breakability.

Foams formed from nanoemulsions (droplet size between 20 and $200 \mathrm{~nm}$ ) are promising formulations given their ability to increase the bioavailability and efficacy of hard-to-dissolve active ingredients by solubilizing them.

Hydroalcoholic (hydroethanolic) foams contain about $60 \%$ ethanol amongst others. Alcohol promotes better skin penetration of active ingredients compared to other vehicles. It alters the barrier properties of stratum corneum reversibly thus enhancing the penetration. The quick evaporation of alcohol from the skin results in fast drying of the foam, therefore it leaves a less unpleasant sticky feeling behind. Rapid evaporation also contributes to the thermolabile property of hydroalcoholic foams, discouraging dispensing foam onto the hands instead of directly to the target area. Owing to the undesired skin-drying property of alcohols, the application of these foams is limited. In addition, skin irritation was reported repeatedly. These side effects lead to the creation of a foam that contains alcohol and still has an emollient effect (e.g. Scytera ${ }^{\mathrm{TM}}$ prepared coal tar $2 \% \mathrm{w} / \mathrm{w}$ foam).

Water-free foams that enable water-insoluble or unstable active ingredients to be used in the form of foams are also under development. The formulation would prevent microorganism growth, making preservatives unnecessary and could maximize the emollient effect [13].

Foam formulations containing aprotic, polar solvents, as dimethyl sulfoxide (DMSO) are under investigation. DMSO is a potent solvent, used as a penetration enhancer as it carries drugs through membranes without damage. According to laboratory studies, DMSO blocks peripheral nerve C fibers; thus the analgesic effect is attributed to it. Anti-inflammatory, antioxidant and membrane stabilizing properties promote DMSO-containing foams beneficial in the treatment of numerous diseases [15].

Amongst aerosol foams two- and three-phase foams can be differentiated (Figure $3 A$ ). By the fore-mentioned, the liquefied propellant is dissolved under high pressure in the mixture of the solvent, the surfactant, and the stabilizing agent. In three-phase foams, the propellant is dissolved in the inner phase of an oil-in-water type emulsion. In this case, the emulsifier and foaming agent could be the same, and vaporized propellant acts as the third phase. Shaking before use is required in the course of both the two- and three phase foams [6].

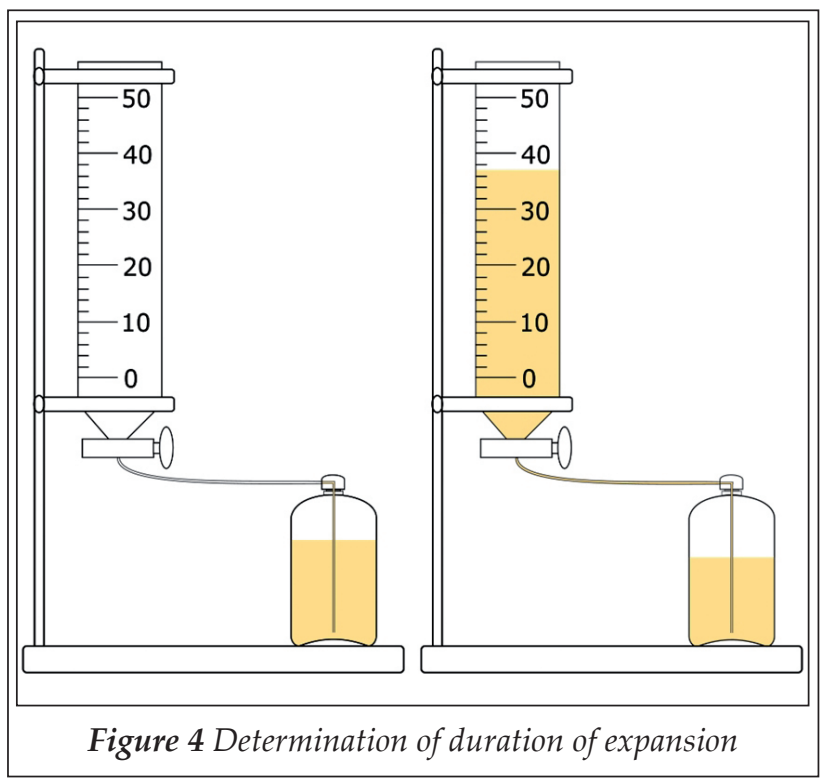


Table II Excipients for liquid foams

\begin{tabular}{l|l}
\hline Solvent & $\begin{array}{l}\text { distilled water, ethanol, isopropanol, glycerine, propylene glycol, di- } \\
\text { methyl isosorbide, DMSO }\end{array}$ \\
\hline Foaming agent & $\begin{array}{l}\text { cetyl alcohol, cetyl stearyl alcohol, sodium docecyl sulfate, sodium ole- } \\
\text { ate, sodium stearate, stearic acid, polysorbate 20 }\end{array}$ \\
\hline Foam stabiliser & $\begin{array}{l}\text { xanthan gum, guar gum, hydroxyethyl cellulose, hydroxypropyl cel- } \\
\text { lulose, hydroxypropyl methylcellulse methyl cellulose, agar-agar, } \\
\text { alginates, sodium lauryl sulfate, lauryl acid, palmitic acid, stearic acid, } \\
\text { coconut oil, tragachant gum, gelatine, glycerine }\end{array}$ \\
\hline Hydrophobic component, emollient & $\begin{array}{l}\text { mineral oils, plant oils, esters (e.g. isopropyl myristate), essential oils, } \\
\text { petrolatum, omega-3 polyunsaturated oil, silicon oil }\end{array}$ \\
\hline Absorption promoter & ethanol, fatty acids, fatty alcohols \\
\hline Foam breaker & alkyl polysiloxanes, oils, alcohols, fatty alcohols, acetone \\
\hline Antifoaming agent & silicone oil, glycerides, polyamide \\
\hline
\end{tabular}

Excipients

Various functional excipients (summarized in $\mathrm{Ta}-$ ble II) are necessary for the preparation of medicated foams. The use of foaming agents, or stabilizers, that can be surface active agents, macromolecular substances that are easily solvated or partially wetting powders is inevitable. [2]. When deciding on the surfactant several factors have to be considered. Although ionic agents are effective they are known skin irritants; consequently, the use of non-ionic surfactants is suggested, especially when inflamed areas are to be treated [14].

Pharmaceutically acceptable oils, like mineral oils, plant oils or triglycerides are mostly chosen as hydrophobic component. Skin protective silicone oils are also preferred, while the greasy petrolatum is less used. Omega-3, Omega-6 polyunsaturated oils or other therapeutically beneficial oils are proven to work even well [14].

\section{Tests, examinations}

The European Pharmacopoeia lists three tests for medicated foams: relative foam density, duration of expansion and sterility. The first one is determined by the m/e ratio, where $m$ is the mass of the foam in grams and $e$ is the mass of the same volume water in grams. It is sufficient if from three measurements the deviation of the values not exceeds $20 \%$ from the mean value.

Duration of expansion is determined in a burette with specified parameters (Figure 4). After thorough shaking the volume of the actuated ca. $30 \mathrm{ml}$ foam is read every 10 seconds until it reaches the maximum volume. It is sufficient if from three measurements none exceeds 5 minutes [10].

Information from the quality of foam can be gained by examining its temporal behavior through time. The reduction of the foam volume can be measured as well as the half lifetime, that is the time it takes the volume of the foam to be halved. Other than these static methods, stationary ones can also be used. In the latter case, it is possible to characterize the foaming agent and the foam itself together. For this a specific device is needed - foaming is induced by streaming gas with constant speed through a perforated membrane and the stationary foam volume is measured when the speed of foam forming and breakdown is equal [2].

There are several tests beyond the pharmacopoeial ones. The circumstances of use are imitated, so the tests are carried out with the lack of propellant, as it evaporates quickly after actuation [13].

Examining the physical properties of foams, like macroscopic appearance, bubble size, foam viscosity and elasticity, is inevitable.

A stereo microscope with digital ocular enables the observation of bubble size and the structure of the foam. With image analysis bubble size distribution, as well as several descriptive parameters (like Feret diameter, area, circularity or roundness) of individual bubbles, like the number of bubbles can be determined. Texture analysis is another method to gain information from the foam structure.

For basic evaluation of foams several methods can be used, including the determination of foam expansion (FE [\%]), foam liquid stability (FLS [\%]), foam volume stability (FVS [\%]) and gas fraction (GF $[\mathrm{ml}])$. These tests provide data on foamability and foam stability [6]. It is important to note, that there is no explicit connection between these two parameters [3].

The following parameters can be determined by filling up a glass cylinder with the foam and recording the initial and the aged volume as well as the volume of drained liquid over time. 


$$
F E(\%)=\frac{V_{\text {foam }}-V_{\text {formulation }}}{V_{\text {formulation }}} \cdot 100 \%
$$

where $V_{\text {formulation }}$ is the volume of the formulation $[\mathrm{ml}]$ required to produce $V_{\text {foam }}[\mathrm{ml}]$. A linear relationship can be found between FE and good foamability.

Foam liquid stability can be calculated as follows:

$$
F L S(\%)=\frac{V_{\text {liquid,30min }}}{V_{\text {formulation }}} \cdot 100 \%
$$

where $V_{\text {liquid,30min }}$ is the volume of drained liquid after $30 \mathrm{~min}$ [ml]. Lower FLS value refers to better stability.

Foam volume stability can be determined by using equation (4).

$$
F V S(\%)=\frac{V\left(\text { foam }_{30 \mathrm{~min}}\right)}{V_{\text {foam }}} \cdot 100 \%
$$

where $V_{\text {foam,30min }}$ is the foam volume after $30 \mathrm{~min}$ [ml]. There is an inverse relationship between FVS and foam stability [6].

Gas fraction, as well as bubble size, vary in wide range depending on the way of application [3]. For the calculation of GF, the following equation is to be used:

$$
G F=V_{\text {foam }}-V_{\text {formulation }}
$$

Turbiscan method, based on Faraday-Tyndall effect, provides another method for the determination of foam stability. The light scattering of colloid solutions is measurable by measuring the intensity of transmitted and backscattered light, that are influenced by the amount of air in the foam. Important to note, that the values vary in time due to foam destabilization.

Carrying out rheological measurements on foams is also circumstantial as for their instability. Oscillatory mode enables the determination of the film elasticity [6].

After dispensing foams, over time, they tend to collapse. Analyzing photos taken periodically can provide information about the time it takes the height of the foam to be halved. This foam collapse time is to be determined at $36{ }^{\circ} \mathrm{C}$. It should take more than 1 minute, so proper application is possible, but 2-3 minutes is ideal [13].

Characterizing quick-breaking foams, due to their short lifetime, with the above-mentioned methods is complicated. In these cases, cryo-SEM (cryogenic scanning electron microscopy) is an alternative method for quantitative foam analysis. Information can be gained aside from morphological parameters, also from bubble size, and bubble size distribution. For these examinations, the foam has to be quickly frozen with liquefied nitrogen and fractured by a precision rotary knife [16].

Krüss Gmbh. has developed a dynamic foam analyser (DFA100) for the scientific analysis of liquid foams. The instrument precisely measures the height of foams, and with the help of the software (ADVANCE, Krüss Gmbh.) data on foam stability, foamability, as well as decay characteristics can be easily obtained. It also enables the quick analysis of bubble size and bubble size distribution by measuring the liquid content. These features ease the optimization of all kinds of liquid foams, including pharmaceutical ones [17].

\section{Dermal foams}

Dermatological preparations on the market are mainly creams, gels or ointments. However, in the last decades the interest in new vehicles, including foams, has significantly increased. This promising formulation is the objective of numerous patents, so it is highly likely that in a couple of years a growing number of foam preparations will be found in the market amongst the traditional pharmaceutical forms [16].

The first known dermatological application of foams belongs to Woodford and Barry. They examined the therapeutic advantages of a quickbreaking hydroethanolic foam containing betamethasone benzoate compared to traditional semi-solid formulations. They reported it effective in psoriasis treatment [18]. Another study reported that a calcipotriol and betamethasone dipropionate-bearing foam reduced the symptoms significantly better than the ointment studied [19].

Based on several other studies foams are proven to be at least as effective and safe as other dermal dosage forms with similar compositions. Patients - regardless of sex, age or ethnicity - considering other properties also prefer foams over traditional formulations [13,18-21].

In case of active ingredients with poor water solubility, foam formulations are advantageous, because with dissolving them in the oil phase of an emulsion foam, higher bioavailability can be reached [13].

Dermal foams, usually containing topical corticosteroids, are mainly used in the treatment of 
skin and scalp dermatoses, like eczema, psoriasis or seborrhoea [12]. According to pharmacopoeial directions, foams have to be sterile when they are used on severely injured skin areas or open wounds [10].

In community pharmacies in Hungary two relevant medicated foams for dermal use are available. Phlogosam (PannonPharma Kft.), sold without prescription, containing dexpanthenol, lidocaine and sodium samarium disulfosalicylate anhydrate for first and second-degree superficial burn, dermatitis solaris or arteficialis and eczema [22].

TEVACARE antidecubitus foam spray is an emulsion foam containing common witch-hazel extract and $\alpha$-bisabolol. In addition to the skin nourishing and regenerating properties, it has cleansing and deodorizing effect. The foam layer helps in even distribution of the mechanical pressure thus reducing decubitus prevalence [23].

\section{Rectal foams}

In the European Pharmacopoeia, the definition of rectal preparations is intended for rectal use in order to obtain a systemic or local effect, or they may be intended for diagnostical purposes' [24]. Local administration is for the adstringent or desinficient effect, but more often steroid-bearing foams are used for the treatment of inflammatory rectal diseases (Chron disease, colitis ulcerosa). Beyond the advantages of rectal administrations, rectal foams have several other favourable properties. On the contrary to suppositories, active ingredient liberates without a latency time form the foam. As they gently fill the rectum, they provide a larger area for absorption. When applied no irritation is experienced derived from the solidity and shape of suppositories. Compared to rectal solutions (klysmae), the application is significantly easier and more convenient, backflow is less likely.

Foam formulations provide good alternative for the rectal application of light and/or oxidationsensitive active ingredients, as can be stored under pressure in a dark container.

As a disadvantage, their low density can be mentioned, for the reason that large API quantities cannot be administered due to the limited volume of rectum $[25,26]$.

In 2009, Dr. Falk Pharma GmbH released Budenofalk ${ }^{\circledR} 2 \mathrm{mg}$ rectal foam. This budesonide-containing preparation for the treatment of colitis ulcerosa, is the first and so far the only rectal foam on the market in Hungary [22].

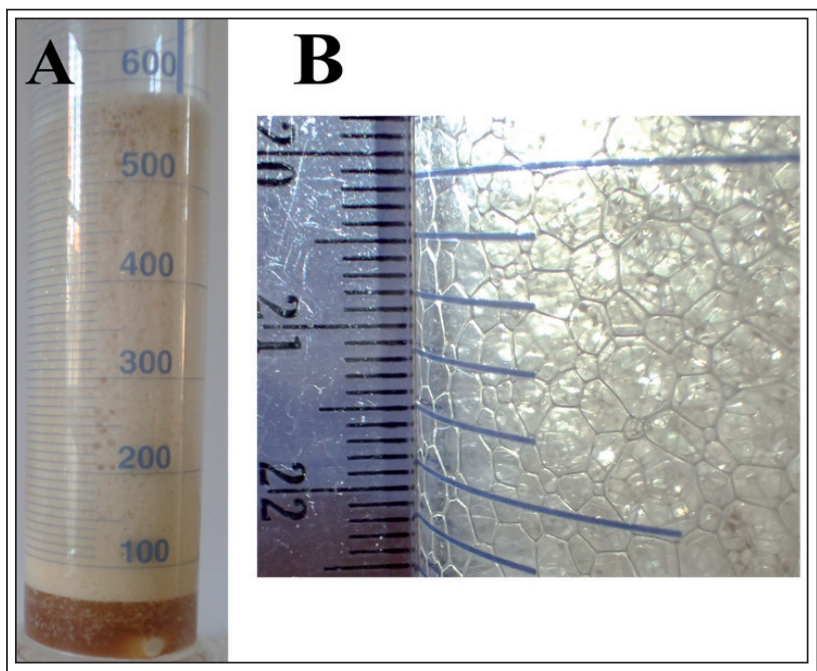

Figure 5 Foam expansion from effervescent intrauterine tablet $(A)$ and the structure of the foam formed $(B)$

\section{Vaginal and intrauterine foams}

Vaginal foams containing spermicides are used as local anticoncipients. There are also vaginal tablets and ovulum, that foams when in contact with cervical mucus. All three compositions are administered precoital. These contraceptive methods are preferred for their effectivity and the lack of contraindications, but in some cases, local irritation was reported. The inconvenience of application is also disadvantageous [27-29].

Antibiotic-bearing foams are also patented for the treatment of vaginal infections [30].

Intrauterine foams containing antibiotics or disinfectants are used in veterinary therapy of endometritis. The gas produced by the effervescent reaction (Figure 5), that helps the homogenous distribution of the active ingredient, as large volume of foam is formed [31].

\section{Dry foams}

In 1974 the effect of a gentamicin-bearing anti-infective dry foam was investigated on Pseudomonas aeruginosa bacteria. Compared with an ointment, they were found to have the same efficacy [32].

Dry foam technology was developed as an alternative method to improve the solubility and bioavailability of active ingredients. A foam formulated from the suspension of the drug was dried under determined circumstances and tabletted after granulation. This method was proven to have better solubility and bioavailability compared to direct compress tablets or wet granulated tablets $[33,34]$. 


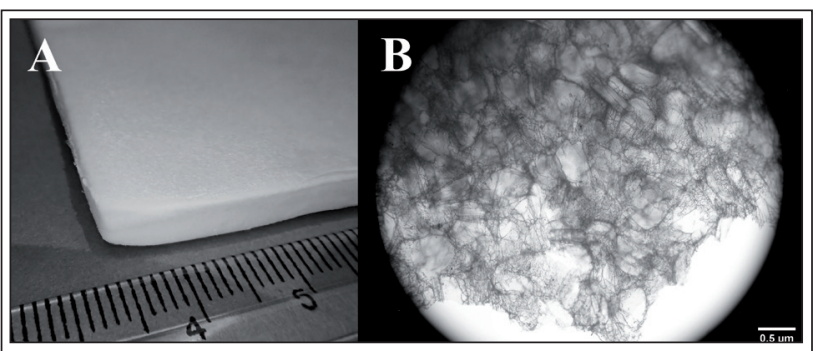

Figure 6 Gentamycin containing foam wound dressing (A) and its microscopic structure $(B)$

\section{Foam dressings}

Over the years, a wide variety of wound dressings appeared on the market for the different wound types. An ideal dressing helps rapid healing while conveniently worn by the patient.

Foam dressings, made of porous polyurethane, have high moisture vapour transmission rate and provide moist, warm circumstances ideal for wound healing. Due to the foam structure, foam dressings have good absorbent properties that enable their use for heavily exuding wounds (Figure 6) $[35,36]$.

In a broad sense, some surgical implants can also be categorised as foams. There are collagenbased gentamicin-impregnated foam implants that can promote the healing of chronic and postoperative wounds by encouraging the wound healing process of the human organism. They ensure local antibiotic concentration higher than the MBC (minimal bactericide concentration) while keeping the systemic level below toxic $[36,37]$.

\section{DepoFoam}

DepoFoam $^{\circledR}$ is a sustained-release, lipid-based multivesicular drug delivery system applied in the form of injections. The name is based on structural similarities with foams, only here the particles contain several internal aqueous chambers separated by a non-concentric continuous network of biocompatible and biodegradable lipid membranes. This unique structure results in high aqueous-volume - liquid ratio (95:5). Subsequently, high drug loading and encapsulation capacity for therapeutic proteins, peptides and water-soluble drugs are provided.

Compared to traditional liposomes DepoFoam ${ }^{\circledR}$ particles are larger. The great size $(1100 \mu \mathrm{m})$ inhibits quick clearance by tissue macrophages and results in depot formation, from where the active ingredient release is sustained without a 'burst' ef- fect. The release profile can be altered by changes in the composition.

The technology was successfully applied with several active ingredients, like interleukins, IGF, insulin, colony stimulating factors and different peptides. DepoCyt ${ }^{\circledR}$ is a clinically investigated intrathecal injection containing cytarabine for the treatment of malignant lymphomatous meningitis, while DepoDur ${ }^{\mathrm{TM}}$ is a morphine-bearing epidural injection for reducing postoperative pain [38-41].

\section{Advantages}

Foams offer a modern alternative in topical treatment. Owing to their good spreadability, fast absorption and easy application (even on large or hirsute areas), foams are preferred to creams or ointments. As rubbing in is not required, the application on sore, inflamed skin areas is painless. Furthermore, the emulsion-based emollient foams can also assist to the hydration of the skin without leaving oily residues and greasy feeling. These contribute to patient acceptance and enhanced compliance and adherence $[12,13,42]$.

\section{Image analysis of foams}

With picture analysis software (ImageJ, public domain program inspired by NIH, US) from photos or microscopic images, data can be gained from the shape, size and size distribution of the bubbles in foams. It enables the examination of the effect of the composition on the structure of the foam, or to follow the structural changes in time.

Figure $7 \mathrm{~A}$ shows a picture (Olympus Stylus TG-4 digital camera, Olympus Corp., Japan) of a foam consisting of $5 \%$ w/w Labrasol ${ }^{\circledR}$ (Gattefossé, France) and distilled water (DW) formed with a propellant-free foam pump device (Figure 3 B, 100 $\mathrm{ml}$, PET from Nordtek Imexco Kft., Hungary). Im-

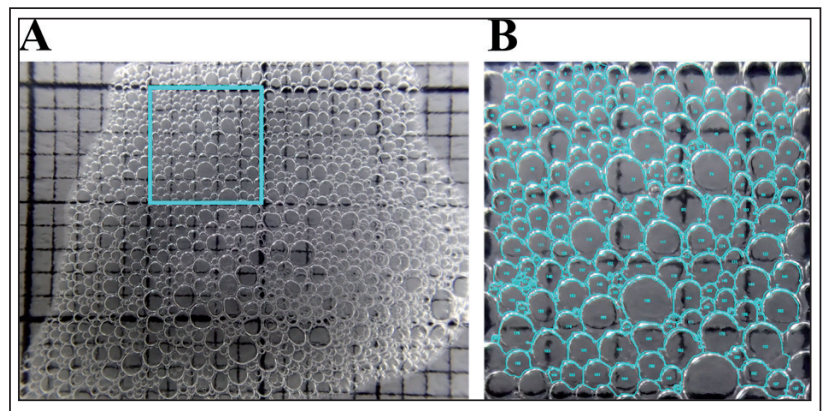

Figure 7 Photo of 5\% w/w Labrasol ${ }^{\circledR}-D W$ foam before (A) and after analysis (B) 


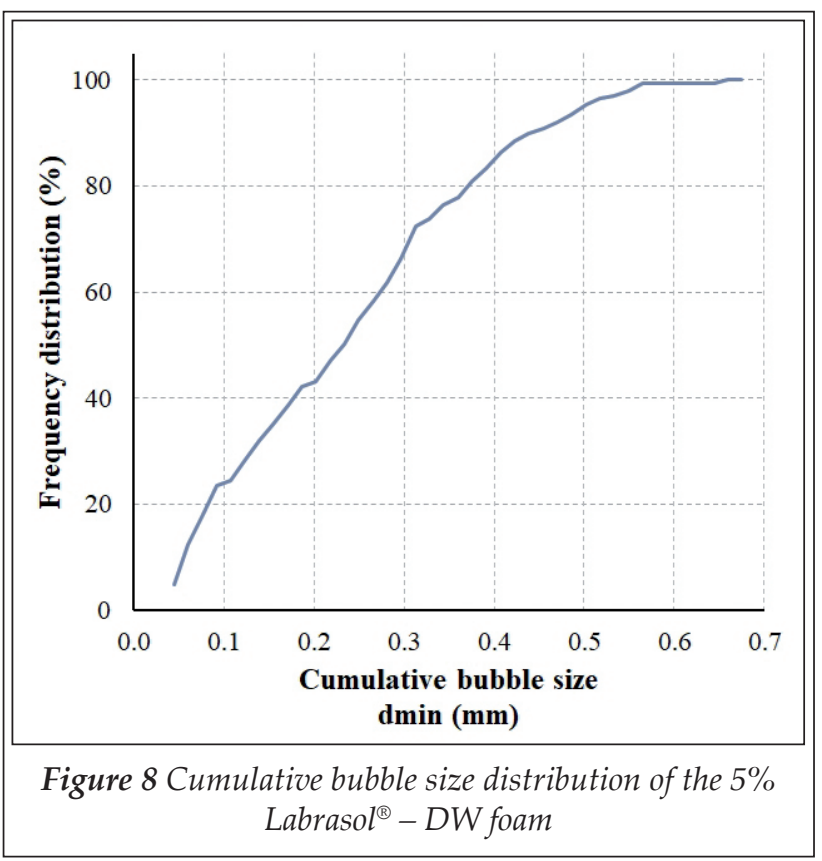

\begin{tabular}{|c|c|}
\hline \multicolumn{2}{|c|}{$\begin{array}{l}\text { Table III Image analysis data characterizing sample } \\
\text { formulation }\end{array}$} \\
\hline \multicolumn{2}{|c|}{$5 \%$ w/w Labrasol ${ }^{\circledast}-$ DW foam } \\
\hline No. & 199 \\
\hline $\operatorname{Sum} A$ & $15.686 \mathrm{~mm}^{2}$ \\
\hline Mean $A$ & $0.079 \mathrm{~mm}^{2} \pm 0.077$ \\
\hline $\operatorname{Min} A$ & $0.003 \mathrm{~mm}^{2}$ \\
\hline $\operatorname{Max} A$ & $0.401 \mathrm{~mm}^{2}$ \\
\hline$D_{v, 0.1}$ & $0.068 \mathrm{~mm}$ \\
\hline$D_{v, 0.5}$ & $0.248 \mathrm{~mm}$ \\
\hline$D_{v, 0.9}$ & $0.411 \mathrm{~mm}$ \\
\hline Span & 0.343 \\
\hline
\end{tabular}

age analysis was accomplished from a $0,5 \times 0,5 \mathrm{~mm}$ photo section (Figure 7 B). The results are shown in Table III Spanvalue was calculated as follows:

$\operatorname{Span}=\frac{D_{v, 0.9}-D_{v, 0.1}}{D_{v, 0.5}}$

where $D_{v, 0.9}: 90 \%$ of the particles are under this diameter, $D_{v, 0.1}: 10 \%$ of the particles are under diameter, $D_{v, 0.5}: 50 \%$ of the particles are under this diameter.

The bubble size data gained from image analysis enables the determination of bubble size distribution. Drawing frequency distribution (\%) over the cumulative bubble size diameter $\left(\mathrm{d}_{\text {min }} ; \mathrm{mm}\right)$ results in the cumulative bubble size distribution graph (Figure 8).

\section{Acknowledgments}

The authors would like to express their gratitude to Gattefossé company and AZELIS Hungary Kft. for providing the Labrasol ${ }^{\circledast}$ sample used for the experiments.

\section{References}

1. Bikerman JJ. General. Foam Films. In: Foams: Theory and Industrial Applications. New York: Springer-Verlag; 1973. p. 1-22. https://doi.org/10.1007/9783-642-86734-7_1

2. Hórvölgyi Z. Habok és emulziók. In: A nanotechnológia kolloidkémiai alapjai. Budapest: Typotex Kiadó; 2011. p. 117-25.

3. Bureiko A, Trybala A, Kovalchuk N, Starov V. Current applications of foams formed from mixed surfactant-polymer solutions. Adv Colloid Interface Sci. 2015;222:670-7. https://doi.org/10.1016/j.cis.2014.10.001

4. Wilson AJ. Foams: Physics, Chemistry and Structure. Berlin/Heidelberg: Springer-Verlag; 1989. https://doi.org/10.1007/978-1-4471-3807-5

5. Rohrsetzer S, Editor. Kolloidika. 4th ed. Budapest: Nemzeti Tankönyvkiadó; 1999.

6. Arzhavitina A, Steckel H. Foams for pharmaceutical and cosmetic application. Int J Pharm. 2010;394(1-2):1-17.https://doi.org/10.1016/j. ijpharm.2010.04.028

7. Langevin D. Influence of interfacial rheology on foam and emulsion properties. Adv Colloid Interface Sci. 2000;88(1-2):209-22. https://doi. org/10.1016/S0001-8686(00)00045-2

8. Kaptay G. Határfelületek energiaviszonyai és alapvető jelenségei. In: Bertóti I, Marosi G, Tóth A, editors. Műszaki felülettudomány és orvosbiológiai alkalmazásai. Budapest: B+V Lap- és Könyvkiadó Kft; 2003. p. 22-46.

9. Petkova R, Tcholakova S, Denkov ND. Foaming and Foam Stability for Mixed Polymer-Surfactant Solutions: Effects of Surfactant Type and Polymer Charge. Langmuir. 2012;28(11):4996-5009. https://doi.org/10.1021/la3003096

10. Council of Europe. Medicated foams. In: European Pharmacopoea 90. 2016. p. 859.

11. Kealy T, Abram A, Hunt B, Buchta R, Abraham A, Hunt $B$, et al. The rheological properties of phar- 
maceutical foam: Implications for use. Int J Pharm. 2008;355(1-2):67-80. https://doi.org/10.1016/j. ijpharm.2007.11.057

12. Purdon $\mathrm{CH}$, Haigh JM, Surber C, Smith EW. Foam Drug Delivery in Dermatology Beyond the scalp. Am J Drug Deliv. 2003;1(1):71-5. https://doi. org/10.2165/00137696-200301010-00006

13. Tamarkin D. Foam: A Unique Delivery Vehicle for Topically Applied Formulations. In: Handbook of Formulating Dermal Applications: A Definitive Practical Guide. 2013. p. 233-7.

14. Tamarkin D, Friedman D, Shemer A. Emollient foam in topical drug delivery. Expert Opin Drug Deliv Expert Opin Drug Deliv. 2006;3(6):799-807. https://doi.org/10.1517/17425247.3.6.799

15. Tamarkin D, Schuz D, Berman T, Hazot Y, inventor. Foamable Vehicles and Pharmaceutical Compositions Comprising Aprotic Polar Solvents and Uses Thereof. United States patent US20120087872A1, 2009.

16. Zhao Y, Jones SA, Brown MB. Dynamic foams in topical drug delivery. J Pharm Pharmacol. 2010;62:67884. https://doi.org/10.1211/jpp.62.06.0003

17. Dynamic Foam Analyzer - DFA100 [Internet]. [cited 2019 Jan 11]. Available from: https://www.krussscientific.com/products/foam-analysis/dfa100/dynamic-foam-analyzer-dfa100/

18. Woodford R, Barry BW. Bioavailability and activity of topical corticosteroids from a novel drug delivery system, the aerosol quick-break foam. J Pharm Sci. 1977 Jan 1;66(1):99-103. https://doi.org/10.1002/ jps.2600660125

19. Queille-Roussel C, Olesen M, Villumsen J, Lacour JP. Efficacy of an Innovative Aerosol Foam Formulation of Fixed Combination Calcipotriol plus Betamethasone Dipropionate in Patients with Psoriasis Vulgaris. Clin Drug Investig. 2015;35(4):239-45. https://doi.org/10.1007/s40261-015-0269-7

20. Elewski BE, Abramovits W, Kempers S, Schlessinger J, Rosen T, Gupta AK, et al. A novel foam formulation of ketoconazole $2 \%$ for the treatment of seborrheic dermatitis on multiple body regions. J Drugs Dermatol. 2007 Oct;6(10):1001-8.

21. Housman TS, Mellen BG, Rapp SR, Fleischer AB, Feldman SR. Patients with psoriasis prefer solution and foam vehicles: A quantitative assessment of vehicle preference. 2002 Dec;70(6):327-32.

22. Országos Gyógyszerészeti és Élelmezés-egészségügyi Intézet [Internet]. [cited 2017 Nov 3]. Available from: https://www.ogyei.gov.hu/

23. TEVACARE antidecubitus habspray [Internet]. [cited 2017 Oct 27]. Available from: http://www.teva. hu/termek-reszletes/deppe-lotio-derm-antidechabspray-400-ml
24. Council of Europe. Rectal preparations. In: European Pharmacopoea 90. 2016. p. 881-2.

25. Stamm A, Cepik SF nee S, Wehrle P, inventor. Composition for foams, notably rectal foams, and foams thus obtained. United State Patent US005725872A, 1996.

26. Healey JNC, Whiteman M, Inventor, Application F, Data P. Pharmaceutical compositions. European Patent application EP0395329A2. p. 1-4.

27. Youssef H, Crofton VA, Smith SC, Siemens AJ. A clinical trial of Neo Sampoon vaginal tablets and Emko Foam in Alexandria, Egypt. Contraception. 1987;35:101-10.https://doi.org/10.1016/S00107824(87)80001-X

28. Brehm H, Haase W. Alternative to hormonal contraception? Significance and reliability of a contraceptive foam ovulum applied vaginally. Med Welt. 1975 Sep 5;26(36):1610-7.

29. Bushnell L. Aerosol foam: a practical and effective method of contraception. Pac Med Surg. 1965;73(6):353-5.

30. Egidio M, Gabriele RL, Subhash D, Massimo G, inventor. Pharmaceutical compositions containing rifaximin for treatment of vaginal infections. United States Patent US006140355A, 2000.

31. Đuričić D, Valpotić H, Žura Žaja I, Samardžija M. Comparison of Intrauterine Antibiotics versus Ozone Medical Use in Sheep with Retained Placenta and Following Obstetric Assistance. Reprod Domest Anim. 2016 Aug;51(4):538-40. https://doi. org/10.1111/rda.12715

32. Catania PN, King JC. Formulation and in vitro Evaluation of Anti-Infective Dry Foams. J Pharm Sci. 1974 Sep 1;63(9):1483-4. https://doi.org/10.1002/ jps.2600630938

33. Sawatdee S, Atipairin A, Yoon AS, Srichana T. Enhanced dissolution of sildenafil dry foam tablets. Asian J Pharm Sci. 2016;11(0):191-2. https://doi. org/10.1016/j.ajps.2015.11.042

34. Dischinger A, Page S, Kleinebudde P. Fast dissolving fillers in dry foam formulation. Powder Technol. 2015;270:494-501. https://doi.org/10.1016/j. powtec.2014.06.036

35. Boateng JS, Matthews KH, Stevens HN., Eccleston GM. Wound Healing Dressings and Drug Delivery Systems: A Review. J Pharm Sci. 2008 Aug 1;97(8):2892-923. https://doi.org/10.1002/jps.21210

36. Zilberman M, Egozi D, Shemesh M, Keren A, Mazor E, Baranes-Zeevi M, et al. Hybrid wound dressings with controlled release of antibiotics: Structure-release profile effects and in vivo study in a guinea pig burn model. Acta Biomater. 2015 Aug;22:155-63. https://doi.org/10.1016/j.actbio.2015.04.029 
37. Griffis CD, Metcalfe S, Bowling FL, Boulton AJ, Armstrong DG. The use of gentamycin-impregnated foam in the management of diabetic foot infections: a promising delivery system? Expert Opin Drug Deliv. 2009 Jun 12;6(6):639-42. https:// doi.org/10.1517/17425240902997919

38. Langston M V., Ramprasad MP, Karali TT, Galluppi GR, Katre NVN V. Modulation of the sustained delivery of myelopoietin (Leridistim) encapsulated in multivesicular liposomes (DepoFoam). J Control Release. 2003 Apr 14;89(1):87-99. https:// doi.org/10.1016/S0168-3659(03)00073-7

39. Ye Q, Asherman J, Stevenson M, Brownson E, Katre N V. DepoFoamTM technology: a vehicle for controlled delivery of protein and peptide drugs.
J Control Release. 2000 Feb 14;64(1-3):155-66. https://doi.org/10.1016/S0168-3659(99)00146-7

40. Katre N V. Lipid Based Multivesicular Carriers for Sustained Delivery of Therapeutic Proteins andPeptides. BioPharm. 2001;14(3):8-9+11.

41. Angst MS, Drover DR. Pharmacology of Drugs Formulated with DepoFoam: a sustained release drug delivery system for parenteral administration using multivesicular liposome technology. Clin Pharmacokinet. 2006;45(12):1153-76. https://doi. org/10.2165/00003088-200645120-00002

42. Shinde NG, Aloorkar NH, Bangar BN, Deshmukh SM, Shirke M V, Kale BB. Pharmaceutical Foam Drug Delivery System: General Considerations. Indo Am J Pharm Res Indo Am J Pharm Res. 2013;3(12):1322-7. 